\title{
Weldability of duplex stainless steels- A review
}

\author{
Aditya Ramesh ${ }^{1 *}$, Vishal Kumar ${ }^{1}$, Anuj $^{1}$, and Pradeep Khanna ${ }^{2}$ \\ ${ }^{1}$ Students, Department of Mechanical Engineering, Netaji Subhas University of Technology, Dwarka, New Delhi, India \\ ${ }^{2}$ Associate Professor, Department of Mechanical Engineering, Netaji Subhas University of Technology, Dwarka, New Delhi, India
}

\begin{abstract}
Duplex stainless steel finds widespread use in various sectors of manufacturing and related fields. It has many advantages due to its distinctive structural combination of austenite and ferrite grains. It is the need of the current generation due to its better corrosive resistance over high production austenitic stainless steels. This paper reviews the weldability of duplex stainless steels, mentions the reason behind the need for duplex stainless steels and describes how it came into existence. The transformations in the heat-affected zones during the welding of duplex stainless steels have also been covered in this paper. The formation, microstructure and changes in high temperature and low temperature heat-affected zones have been reviewed in extensive detail. The effects of cooling rate on austenite formation has been briefly discussed. A comparison of weldability between austenitic and duplex stainless steel is also given. Finally, the paper reviews the applications of the various grades of duplex stainless steel in a variety of industries like chemical, paper and power generation and discusses the future scope of duplex stainless steel in various industrial sectors.
\end{abstract}

\section{Introduction}

Stainless steel was developed in the early 20thcentury. Production techniques at that time, however, resulted in higher amounts of carbon in these steels. A material was considered to have great potential at that time because of its various characteristics over other plain carbon alloy steels. Nevertheless, during heat treatment, the initial grades of stainless steel were prone to grain boundary carbide precipitation, welding and intergranular corrosion attack. This shortcoming limited its use and led to the invention of a new category of stainless steel in 1929, called duplex which contains a two-phase structure (ferriticaustenitic) ranging from $30 \%$ to $70 \%$ [1].

The material was continuously upgraded from 1950 to 1951 until the Korean War led to the shortage of nickel which encouraged the researchers to develop other grades of this material with low nickel. To overcome this shortage, an attempt was made to add titanium to the 300 Series austenitic steel $[2,3]$. The addition of titanium pinned the grain boundaries that confined the enormous ferrite grain growth in the heat-affected zone due to the formation of chromium from carbides by titanium. This provided the foundation for the discovery of the second generation of duplex $[4,5]$.

Even though this grade was a breakthrough in alloy design, it was still vulnerable to intergranular corrosion in a few conditions. It was believed that an almost fully ferritic heat-affected zone after welding can be activated due to the high chromium/nickel equivalent ratio [6]. Also, ferrite has a low solubility of nitrogen and carbon which led to carbide and nitrides precipitation along the grain boundaries eventually resulting in the $\mathrm{Cr}$ depletion of the matrix called sensitisation [7]. To eliminate this issue, nitrogen and nickel were introduced in a higher concentration. The early 1970 s saw the development of a duplex grade that had a $22 \% \mathrm{Cr}$ content coupled with a balanced chemistry $(\mathrm{Cr} / \mathrm{Ni}$ equivalent ratio) which upon welding was not susceptible to intergranular corrosion. This development established the production and welding metallurgy and laid the foundation for the 3rd generation of duplex alloys [8].

To withstand more aggressive environments, more highly alloyed duplex grades with addition of tungsten, higher levels of nitrogen and balanced $\mathrm{Cr}$ and $\mathrm{Ni}$ forming elements called super duplex grades were invented during the 1980s. On the other hand, these grades having higher alloy contents encouraged intermetallic precipitation which led to reduction in properties [9]. This shortcoming led to the development of lean duplex which had a lower alloy content, especially Molybdenum. Compared with standard grades, lean duplex is economical to make but has a lower pitting resistance. Lean duplex successfully contests with high production austenitic grades like $304 \mathrm{~L}$ and $316 \mathrm{~L}$ on the account of its greater strength, better resistance to chloride stress

\footnotetext{
*Corresponding author: ra.mp18@nsut.ac.in
} 
concentration cracking and having similar pitting resistance in chloride media [10]. Since duplex stainless steel shows many advantages over austenitic stainless steel, this paper reviews the weldability of duplex stainless steel and the change in its microstructure in the high temperature and low temperature heat-affected zones. The effect of cooling rate on its composition has also been studied. On the basis of welding aspects, this paper also compares austenitic and duplex stainless steels.

\section{Weldability of duplex stainless steels}

There has been a vital contribution of welding metallurgy in the evolution of duplex stainless steel. Many welding processes like submerged arc welding, gas tungsten arc welding, plasma arc welding and gas metal arc welding have been successfully performed on duplex stainless steels to facilitate high design and service requirements [11]. The welding process is chosen based upon the type of joint, fabrication economics and the material thickness. A ferrite-rich heat affected zone (HAZ) was formed due to the high carbon contents of the earliest grades. In spite of the austenite reformation, carbide precipitation increase and intergranular corrosion (IGC) resistance loss was observed among the earlier grades. The high $\mathrm{Cr} / \mathrm{Ni}$ ratio in the later grades with low carbon levels supplemented the ferrite-rich microstructures in the heat affected zone, thus assisting the grain growth [11]. A duplex stainless steel with $22 \% \mathrm{Cr}$ content was developed in the early 1970 's. The patent established that upon welding, this steel was resilient to intergranular corrosion due to its balanced chemistry and the inclusion of nitrogen. Fully ferritic heat affected zones with a corresponding reduction in corrosion resistance were also produced by melts whose composition ranges were very wide $[8,12]$.

\subsection{Transformations in the heat affected zones during the welding of duplex stainless steels}

As shown in figure 1, the high temperature heat affected zone (HTHAZ) is the zone adjacent to the fusion line that approaches the melting point and will nearly become wholly ferritic on heating [13]. The fusion zone in duplex stainless steel 2205 [14] is depicted in figure 2. The low temperature heat affected zone (LTHAZ) is the zone next to the base metal where the phase balance has been retained. There are transitions among the low temperature and high temperature heat affected zones whose intricacy escalates further if recurrent exposures from multi-pass welds are superimposed [11]. The microstructure of weld metal zone and the microstructure at fusion line [14] is shown in figure 3.

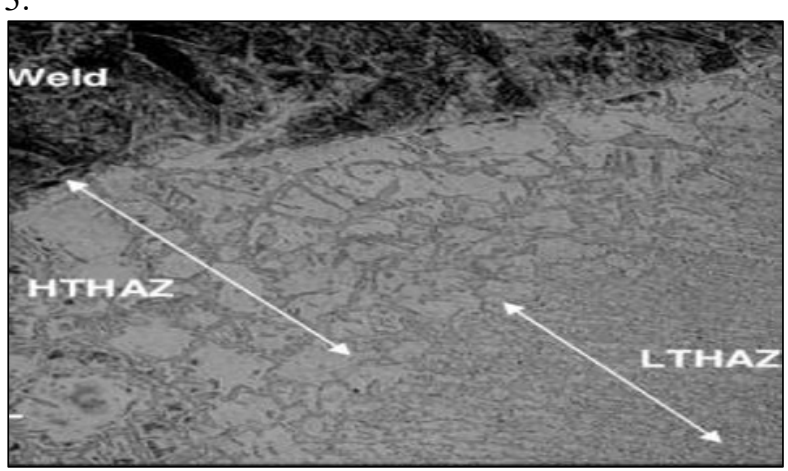

Fig. 1. Formation of HTHAZ and LTHAZ [13]

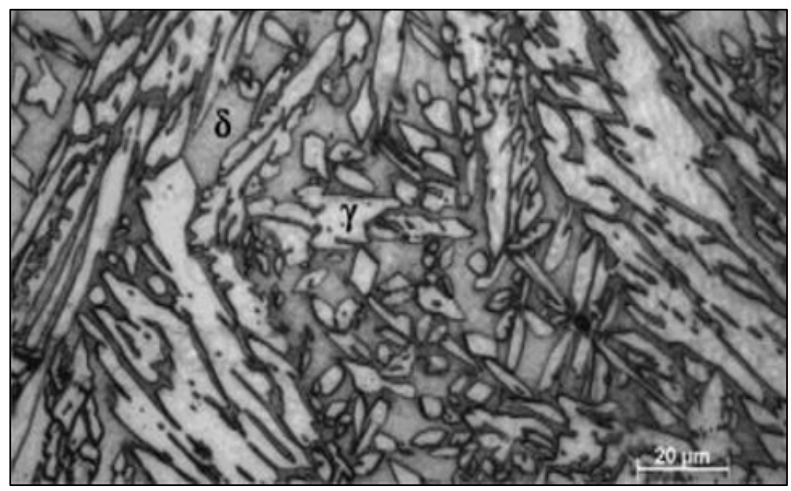

Fig. 2. Fusion zone in duplex stainless steel 2205 [14]

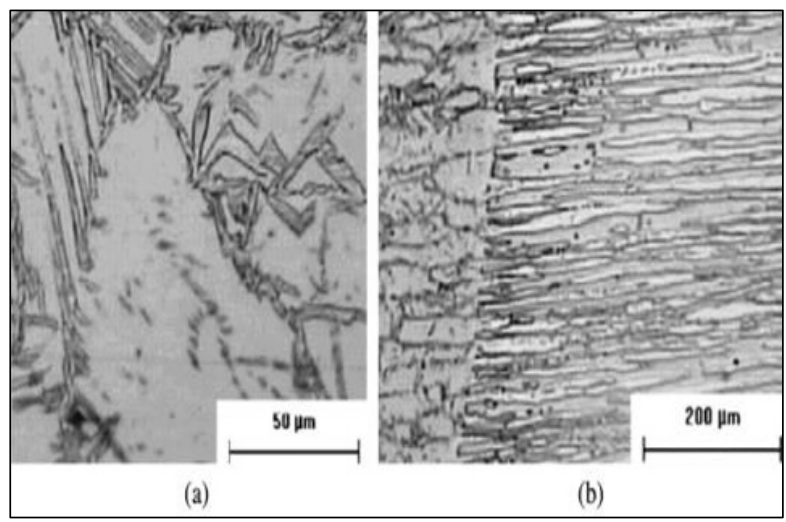

Fig. 3. (a) Microstructure of weld metal zone $(50 \mu \mathrm{m})$ (b) Microstructure at fusion zone $(200 \mu \mathrm{m})[14]$

The steel composition and the welding procedure primarily controls the transformed microstructure in the high temperature heat affected zone $[15,16]$. Austenite formation is hindered by a large ferrite grain size $[17,18]$. A fully ferritic zone decreases the solubility of nitrogen and carbon. This causes the nitrides and carbides to precipitate along the grain boundaries resulting in the local $\mathrm{Cr}$ depletion of the matrix, making the steel less tough and prone to brittle failures in service [19]. For the arc energies generally used in the industry, the complications linked with the fully ferritic zones have been resolved by improving the chemical constitution of the base material. This had extensively been 
achieved by enhancing the nitrogen content of the steels [11]. Hence provided suitable welding processes are used, the modern duplex steels usually have ferrite levels in the high temperature heat affected zones in the range of 50-70\% [2]. The ferrite grain size and austenite dissolution are controlled by the duration of exposure to single phase ferritic region and the peak temperature [15, 20]. In rapidly cooled welds, lower temperature reactions may transpire in the HTHAZ, such as nitride formation if inadequate austenite reformation [21] occurs [17, 22]. Occasionally, a precipitate free zone next to the austenite phase is observed in the ferrite due to the diffusion of nitrogen essential for nitride precipitation to the austenite [23, 24]. The low temperature heat affected zone has a thermal history which might result in the formation of intermetallic phases and is also found further away from the fusion line [25]. Predominantly this is a drawback faced by the higher alloyed superduplex stainless steels, but it can also affect lower alloy grades with extremely slow cooling rates $[26,27]$. Slower cooling rate results increases the austenite formation whereas faster cooling rates results in lesser austenite [11, 28]. These results [14] have been shown in table 1 .

Table 1. The concentration of different phases of duplex stainless steel 2304 at varied cooling rates [14]

\begin{tabular}{|l|l|l|}
\hline $\begin{array}{l}\text { Cooling rate } \\
(\mathbf{C} / \mathbf{s})\end{array}$ & Ferrite (\%) & Austenite (\%) \\
\hline 100 & 72.2 & 27.8 \\
\hline 50 & 71.5 & 28.5 \\
\hline 30 & 68.4 & 31.6 \\
\hline 20 & 66.1 & 33.9 \\
\hline 10 & 64.3 & 35.7 \\
\hline
\end{tabular}

The welding parameters must be managed such that overall cooling conditions are quick enough to evade the harmful precipitation in the low temperature heat affected zone and simultaneously slow enough for sufficient austenite formation in the high temperature heat affected zone. These guidelines have traditionally provided the maximum interpass temperatures and the recommended heat input ranges. Since the effect of the material thickness and the joint geometry also requires consideration, this technique does not entirely explain the appropriate thermal cycles for optimum properties [11]. Hence, cooling rates play a pivotal role in deciding the concentration of the various phases of duplex stainless steel and the changes in the heat-affected zone affects it microstructure.

\section{Comparison between Austenitic \& Duplex stainless steel}

Presently, austenitic stainless steels are widely used in all the industries. Duplex stainless steels are a good alternative to austenitic. It has many advantages over austenitic stainless steel like corrosion resistance and higher strength. It is important to know the welding aspects of both austenitic and duplex stainless steels to understand the merits and demerits of one over the other. Table 2 compares the major welding aspects of austenitic and duplex stainless steels.

Table 2. Comparison between austenitic and duplex stainless steels [29]

\begin{tabular}{|c|c|}
\hline $\begin{array}{l}\text { AUSTENITIC } \\
\text { STAINLESS STEEL }\end{array}$ & $\begin{array}{l}\text { DUPLEX STAINLESS } \\
\text { STEEL }\end{array}$ \\
\hline $\begin{array}{l}\text { Most weldable among } \\
\text { the high alloy steels, } \\
\text { supports all the } \\
\text { resistance and fusion } \\
\text { welding processes. }\end{array}$ & 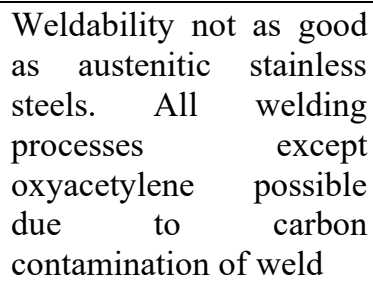 \\
\hline $\begin{array}{l}\text { Small percentage of } \\
\text { delta ferrite found in the } \\
\text { final weld metal } \\
\text { structure, which is the } \\
\text { indication of a sound } \\
\text { weld }\end{array}$ & $\begin{array}{l}\text { Solidification takes place } \\
\text { with fully ferritic } \\
\text { structure along with grain } \\
\text { growth and austenite } \\
\text { nucleation while cooling. }\end{array}$ \\
\hline $\begin{array}{l}\text { Filler metals over } \\
\text { alloyed with chromium, } \\
\text { nickel and } \\
\text { molybdenum to } \\
\text { increase the resistance } \\
\text { to corrosion. Nickel- } \\
\text { based fillers used for } \\
\text { austenitic grades with } \\
\text { highest alloys. }\end{array}$ & $\begin{array}{l}\text { Filler metals have } \\
\text { increased nickel content } \\
\text { to obtain phase balance } \\
\text { analogous to the base } \\
\text { metal. }\end{array}$ \\
\hline $\begin{array}{l}\text { Weld metal causes the } \\
\text { problem in welding. } \\
\text { For example- hot } \\
\text { cracking which can be } \\
\text { resolved by controlling } \\
\text { the lower heat input. } \\
\text { Usually necessitates } \\
\text { multiple passes to make } \\
\text { up the weld. }\end{array}$ & $\begin{array}{l}\text { Heat affected zones } \\
\text { causes the problems in } \\
\text { welding. For example- } \\
\text { loss of corrosion } \\
\text { resistance which is } \\
\text { overcome by decreasing } \\
\text { the total time spent at the } \\
\text { temperature in "red hot" } \\
\text { range rather than } \\
\text { managing the total heat } \\
\text { input during a single pass. }\end{array}$ \\
\hline $\begin{array}{l}\text { Welding speeds are } \\
\text { faster due to good weld } \\
\text { penetration and good } \\
\text { weld pool fluidity. }\end{array}$ & $\begin{array}{l}\text { Relatively lower welding } \\
\text { speeds due to poor weld } \\
\text { penetration and fluidity. }\end{array}$ \\
\hline
\end{tabular}




\section{Industrial applications of different grades of duplex stainless steels}

Duplex stainless steel finds widespread used in all the major industries. Different grades of duplex stainless steel are used for different purposes. They are extensively used in the power generation, oil and natural gas, paper, chemical and petrochemical and fuel gas desulphurisers industries. Due to their greater strength and corrosion resistant properties, they are widely being used in place of austenitic stainless steel in many manufacturing industries. It is also economical since it has a similar cost to austenitic stainless steel. Many industries are increasing the use of duplex stainless steels and are also looking to use them in other fields. A few industrial applications of different grades of duplex stainless steels are listed below [11].

\subsection{Standard duplex EN1.4462}

It is widely used in the injection pipes of a geothermal well in the power generation industries [30]. It is also used in the framework, down-hole tubing and in the slotted oil liner of an oil and natural gas industry. In the paper industry, it is used in an $\mathrm{O}_{2}$ impregnator and in the digester of a sulphite and sulphate plant $[31,32]$. In the chemical and petrochemical industry, it is widely used in a variety of processes like distillation and desalination. It is also used in a melting coil and a centrifuge. It finds extensive use in a centrifugal fan of the fuel gas desulphurisers industry.

\subsection{Lean duplex EN1.4362}

It is mainly used in the pump and diving bell of the oil and natural gas industry. In the paper industry, it is extensively used in the pre-heater of a digester. It is also used as an impedimenta for desulphurisation in the chemical and petrochemical industries. It finds widespread use in a pump casing. In the fuel gas desulphurisers industry, it is mainly used in the liner of an evaporator tower.

\subsection{Lean duplex EN1.4417}

In the power generation industries, it is used in the re-heaters and in a feed water heater. It is also used in the tensioning and piping system of the oil and natural gas industry. It is widely used in an evaporator and in the storage tank of bleaching pulp in paper industry [33]. It finds an extensive use in the tubular reactor of the chemical and petrochemical industries.

\subsection{Super duplex EN1.4507}

In the power generation industry, it is used in pumps and in the heat exchanger of a geothermal well and saline brine $[34,35]$. It is also widely used in a valve block, seawater cooling system and pressure vessel of the oil and natural gas industry [36-38]. In the paper industry, it is used an impedimenta for bleaching. In the chemical and petrochemical industries, it is used in the $\mathrm{HCl}$ and chloride media of pipes and tubes [39]. It is also used in the pumps and in a seawater cooling system.

\section{Future scope and challenges of duplex stainless steel}

The Global Duplex Stainless Steel Market estimates a CAGR of over $5 \%$ during the upcoming forecast period (2021-2026). Duplex stainless steel finds major applications in the civil and structural industry. It is used as a construction design material due of its inimitable characteristics, such as improved strength when compared to carbon steel and higher corrosive resistance as compared to austenitic stainless steel [2].

\subsection{Future scope in end-use industry}

\subsubsection{Oil \& Gas Industry}

Oil and gas industry uses multiple grades of duplex stainless steel due to their enhanced corrosion and stress resistance. It can be used in the pipelines carrying acidic oil and gas, scrubbers, flow lines and separators in a variety of industries in the near future. [11].

\subsubsection{Chemical Industry}

Presently, it finds extensive use in the manufacturing of pressure vessels, water heaters and chemical reactors. Its requirement is increasing day-by-day in the chemical industry. It will play a huge role in the future growth and success of this industry [11].

\subsubsection{Paper Industry}

It is extensively used in digesters and reactors. It has a huge potential for extensive use in oxygen reactors and pulp processing in the near future. [40].

\subsubsection{Civil and Structural Industry}

It can be widely used in the civil industry primarily in the coastal areas as a structural design material. $[41,42]$ due of its inimitable characteristics as mentioned above [2]

\subsection{Challenges in welding of duplex stainless steels}


There is a reduction in properties due to intermetallic precipitation of higher alloy duplex. So, the heat input should be controlled and continuously monitored. Presently, the heat-affected zone of the duplex stainless steel is an area of concern due to its lower toughness and post-weld cracking. Pitting in the heat-affected zone of a duplex stainless steel makes the base metal weak. So, due care must be taken to avoid it. Diffusion of alloying element like nitrogen leaves almost fully ferritic fusion line. This is an important concern which must be addressed. One of the major drawback of duplex stainless steel is the inability to achieve higher welding speeds due to the poor weld penetration and fluidity in weld pool. Further research needs to be done to overcome this issue. Nitrogen content in shielding gas should also be controlled as it may cause embrittlement. These are a few challenges faced during the welding of duplex stainless steel. To overcome these challenges, further research of duplex stainless steel must be enhanced. If these challenges can be addressed, duplex stainless steel will find a widespread use in all the sectors of manufacturing.

\section{Conclusion}

Duplex stainless steel is slowly replacing austenitic stainless steel in major industries due to its better strength and corrosion resistance properties. The heat input, composition of work piece material and the cooling rate are the primary challenges in obtaining the desired ratio of austenite and ferrite phases during the welding of duplex stainless steels. The high temperature and low temperature heat affected zone plays a vital role in the weldability of duplex stainless steels. Due to its balanced chemistry, it is not sensitive to intergranular corrosion upon welding and can be used in aggressive environments. Many industries like construction and chemical are successfully incorporating the use of duplex stainless steels due to its enhanced properties. Duplex stainless steel can be widely used in all the manufacturing sectors if better control of welding parameters can be achieved.

\section{References}

1. E.C. Bain, W.E. Griffiths: Trans AIME, 75,16 (1927)

2. J. Charles: Conf proc Duplex Stainless Steels '91, Beaune, Les editions de physique, Vol. 1,4 (1991)

3. K.A. Yushchenko, A.K Avdeeva: Conf proc Welding Technology Paton Institute, Cambridge, TWI, October'93, Paper 1 (1993)

4. S. Henriksson, L. Knutsson: British Corrosion Journal'75 10 (3), 128 (1975)

5. J. Olsson, S. Nordin: Proc conf The Hague '86, vide ref. 11, paper 48,219 (1986)
6. J. Olsson, M. Liljas: Conf Corrosion'94, NACE, Baltimore, paper 395 (1994)

7. German patent DT 2225 673, Sudwestfalen (Krupp) (1972)

8. J.M.A. Quik, M. Guedeke: Conf Corrosion '94, NACE, Baltimore, paper 393 (1994)

9. J. Pleva, S. Nordin: Proc conf Duplex Stainless Steels '82, St Louis, ASM, 603 (1983)

10. H. Okamoto: Confproc Applications of Stainless Steel'92, Vol. 1, Stockholm, Jernkontoret, 360 (1992)

11. R. N. Gunn, Duplex Stainless Steels: Microstructure, properties and applications, Woodhead Publishing (1997)

12. German Patent Application DT 2255673 (1972)

13. Du Toit, Madeleine \& van Rooyen, Gerrit \& D. Smith, Heat-Affected Zone Sensitization and Stress Corrosion Cracking in 12\% Chromium Type 1.4003 Ferritic Stainless Steel. Corrosion. 63. 10.5006/1.3278392 (2007)

14. A. Pramanik, G. Littlefair and A. K. Basak: Weldability of Duplex Stainless Steel, Materials and Manufacturing Processes

15. J.C. Lippold, I. Varol, W.A. Baeslack III: Conf proc Duplex Stainless Steels'91, Beaune, Les editions de physique, 1,383 (1991)

16. T.G. Gooch: Conf proc Duplex Stainless Steels, St Louis, ASM,573 (1983)

17. S. Hertzman, W. Roberts, M. Lindenmo: Conf proc Duplex Stainless Steels'86, The Hague, Paper 30, 257 (1986)

18. R. Mundt, H. Hoffmeister: Arch. Eisenh. 54, 333 (1983)

19. H. Hoffmeister, R. Mundt: Arch Eisenh 52 , 159 (1981)

20. P.J. Ferreira, S. Hertzman: Beaune '91, vide ref. 3, Vol. 2,959-966 (1991)

21. B. Bonnefois, J. Charles, F. Dupoiron, P. Soulignac: Beaune'91, vide ref. 3, 1, 347 (1991)

22. C.V. Roscoe, K.J. Gradwell, G.W. Lorimer: Conf proc Stainless Steels'84, Goteborg, The Institute of Metals, 563 (1984)

23. M. Liljas, R. Qvarfort: The Hague '86, vide ref. 8, paper 2, 244 (1986)

24. R. Mundt, H. Hoffmeister: Conf proc Stainless Steels '84, Gothenburg, The Institute of Metals, 315 (1985)

25. L. van Nassau: Welding in the World 20,23 (1982)

26. P.L. Bowden, J.L. Ward: Conf proc 25th Annual OTC, May'93, Houston, Texas, OTC 7316, 545 (1993) 
27. K. Ume, N. Seki, Y. Naganawa, T. Hyodo, K. Satoh, Y. Kuriki: Corrosion'86, Houston, NACE, paper 155 (1986)

28. O.N. Noble, T.G. Gooch: Welding Institute Report 321/1986, November (1986).

29. Practical Guidelines for the Fabrication of Duplex Stainless Steels, International Molybdenum Association ISBN 978-1907470-00-4 (2009)

30. D.J.A. Fruytier: Beaune'91, vide ref. 2, 1,497 (1991)

31. F. Dupoiron, M. Verneau, J.P. Audouard, J. Charles: Glasgow '94, vide ref. 1, 3, paper 92 (1994)

32. P. Audouard, A. Desestret, G. Vallier, J. Chevassaut, J.P. Mader: Conf proc 3rd International Symposium on Corrosion in the Pulp and PaperIndustry, Atlanta, May (1980)

33. J.P. Audouard: Conf proc 4th International Symposium on Corrosion in the Pulp and Paper Industry, Stockholm, May/June (1983)

34. S. Winnik, B.J. Fitzgerald: Corrosion'94, Baltimore, NACE, paper 390 (1994)

35. A.B. Sandvik Steel: The role of duplex stainless steels in oil refinery heat exchanger applications, S-1541·ENG, September (1996)

36. K.A. Johansson: Proc conf Duplex Stainless Steels, Glasgow, TWI, Vol. 3, paper KVII (1994)

37. R. Francis: Industrial Corrosion, 10, 12 (1992)

38. G.H. Wagner, J.K.L. Korkhaus: Confproc Duplex Stainless Steels'94, Glasgow, TWI, Vol. 3, paper KVIII (1994)

39. R.F. Smith, A. Pennington: Corrosion'94, Baltimore, NACE, paper 389 (1994)

40. A. Wensley, C. Reid: Stainless Steel Europe, 32-38, April (1992)

41. Nickel Development Institute: Nickel 12(3), Spring, 12 (1997)

42. E.F.C. Publication No. 18: Stainless steel in concrete. State of the art report, European Federation of Corrosion/The Institute of Materials (1996) 